\title{
POSTMODERNITY AND LATE CAPITALISM: READING OF ANDERSON AND HARVEY
}

\author{
Saroj Koirala*
}

ABSTRACT

This article deals with two pioneer scholars of postmodernism, David Harvey and Perry Anderson. The former disagrees with Jameson's response to postmodern condition, and the latter concentrates on the economic and geopolitical conditions that have nurtured the idea and changes. However, both of them are aware of the totality of contemporary life. Postmodern condition, for Harvey, is dangerous as it avoids the issues of the realities of political economy and global power. He opines that capitalist response to 1973 economic crisis openly attacked the rigidity of Fordism, which consequently gave birth to the postmodern condition. Harvey perceives postmodernism as people's aesthetic and cultural response to unprecedented. Though these critics adopt different approaches both agree with the claim that postmodern is encompassing the totality of our life experience. Finally, the article exemplifies how this generalization is working in popular Indian culture particularly focusing on Valentine Day celebration. The role played by Indian media has changed the society and culture which might be similar to Nepalese context. Thus, postmodern condition elaborated by Harvey and Anderson are not delimited to the first world but also seem relevant in the socalled third world.

Key Words: Aphoria, crystallization, ephemerality, geneology, geopolitical, kitsch, meta-narrative, pastiche.

David Harvey's The Condition of Postmodernity and Perry Anderson's The Origins of Postmodernity present a critical assessment of the postmodern condition. Anderson examines the genealogy of the term postmodern in his book. His argument resides in the central figure of Fredric Jameson, who, according to Anderson, not only fully mapped the scope of the term but also "identified [it] with a new stage of capitalism, understood in classical Marxist terms" (64), and thereby, Anderson states that Jameson has set the "terms of subsequent debate" (78). Notwithstanding Anderson's positioning of Jameson as the central figure who wrested postmodernism from being conceded to the Right, David Harvey finds faults with Jameson's

Dr. Koirala is Reader in English at Prithvi Narayan Campus, Tribhuvan University, Pokhara, Nepal. 
response to the postmodern condition which he terms as an attempt to "try and ride the tiger of time-space compression through a construction of a language and an imagery that can mirror and hopefully command it" (351). $\mathrm{He}$ argues that such "hyper-rhetoric [...] can dissolve into the most alarming irresponsibility" (351). For him, therefore, the postmodern condition is the result of the unprecedented time-space compression created by the capitalist system's attempt, through flexible accumulation, to stabilize itself after one of its many crises through history. According to him, our understanding of the contemporary condition of ephemerality, fragmentation and fleeting images and our ability to counter-attack with a narrative can be possible only with historical materialism which will enable us to confront the realities of political economy and the circumstances of global power that postmodernism avoids.

From the above comparison, it is fair to assert that the nature of the two books differs significantly. Anderson's project relies more on tracing the key changes of the term postmodern and less on the speculation of the economic and geopolitical conditions that have produced the idea and the changes. Harvey, on the other hand, does the latter and locates economic reasons, more particularly flexible accumulation, as the major factor for the conditions of postmodernity. In spite of the divergent ideas propelling their projects, the two writers' analysis and discussion provide critical insights into postmodernism as a phenomenon that has come to encompass the totality of our day to day life.

Anderson surveys the concept of postmodernism attributing to the earliest coinage of "postmodernismo" to a Hispanic Federico de Onis, who first used the word in the 1930s. Subsequently, his narrative traces its intellectual conceptualization from the historian Arnold Toynbee in 1954 to the American poet Charles Olsen, and consequently to Ihab Hassan, Robert Venturi, Charles Jencks, the philosophical discussion of Jean-Francois Lyotard and Juergen Habermas, and ultimately culminating with Fredric Jameson's capture of the term. According to Anderson, Ihab Hassan wrested the "poststructuralist motifs" (18) to distinguish between modernist and postmodernist paradigms and declared that the "underlying unity of the postmodern lay in the play of indeterminacy and immanence" (18). Anderson, however, critiques Hassan because he failed to make any substantial connection between the artistic and social tendencies of the postmodern phenomena though he suggested its existence. Robert Venturi and his associate Denise Scott Brown, in their book Learning from Las Vegas, made the next logical move. Writing about architecture, they did not moralize about the excessive commercialization of Las Vegas. Examining the contrast between "planned monotony of modernist mega structures with the vigor and heterogeneity of spontaneous urban sprawl" (21), they showed the 
connection between art and society by distinguishing between "Building for Man' vs. 'Building for men (markets)"' (21). But till then, Venturi did not have an expression to describe his program, which was "expressedly designed to supercede the modern" (21). Subsequently, with the publication of Charles Jencks's Language of Post-modern Architecture in 1977, the distinction of postmodern and late modern in architecture was firmly established. Jencks posited the idea of "employing a hybrid of modern and historic syntax [...] appealing both to educated taste and popular sensibility" (22). Jencks, according to Anderson, celebrated this new sensibility of "a world civilization of plural tolerance and superabundant choice, that was 'making nonsense' of such outmoded polarities as 'left- and right-wing, capitalist and working class" " (23) besides the quietus of the avant-garde.

Anderson further explains that until then the term postmodern was used to describe aesthetic movement, but its philosophical crystallization and treatment as a general condition of human circumstances was the outcome of the discussion by Jean-Francois Lyotard. His La Condition Postmodern published in Paris in 1979 speculates that the defining trait of the postmodern condition is the loss of credibility of the modern meta-narratives (as exemplified by the demise of the Enlightenment progress) and their replacement by mini narratives (26). Anderson, however, points that even after communism's fall, Lyotard would still not attribute legitimation to the rise of capitalism as another round of meta-narrative for he described it as "a story without historicity or hope [...] [and] no finality in any horizon of emancipation" (34). Anderson finds faults with Lyotard in this regard for in his earlier account of meta-narratives he had not limited them to the notion of emancipation. Indeed, he explains that Lyotard in a different note elsewhere speaks of emancipation originating from within the new system rather than from without. So, there is aporia in Lyotard's analysis because from within his declaration of the demise of meta-narratives, he strangely proceeds toward resurrecting another "allegory of development" (35).

Besides, Anderson points out that Habermas, with his agenda of completing the project of modernity, provided "the negative pole for [postmodernism's] productive tension" (36), and speaking from the Left only handed the ground to the Right. Interestingly, for Anderson, within Lyotard and Habermas's philosophical discourse on postmodernism, they fail to perceive the concept from a historical perspective when the name itself by definition suggests temporality. Both fail to bring postmodernism into sharper focus, even while they deal from within the principles of high modernism. For Anderson, however, all of these discourses, though dispersed, have a unity of theme and ideology. He declares that the notion of postmodernism 
"in one way or another [was] an appanage of the Right" (45). He, therefore, asserts that Hassan's celebration of play and indeterminacy as the hallmark of postmodernism against the "iron yolk of the Left" (45); Jencks's merriment at the passing of the modern as the liberation of choice; Lyotard's theorizing of the rise of mini narratives against the last grand narrative-Marxism; and Habermas's argument though positioned on the Left but conceding the idea to the Right, all point to the overall domination of the capitalist system. The logical conclusion, therefore, would not just be to link the rise of the postmodern condition to the domination of capitalism but to relate its evolution to the historical and political-economic condition of the rise of capitalism. But such a deduction was yet to be undertaken.

Such was the stage when Jameson entered the fray. As a literary critic he came to the concept of postmodernism because he noticed a lacuna between aesthetic forms in art and its social implication. He found realism, which he associated with classical capitalism, to be outdated in explaining modern experience. The following notion of modernism, which he associated with consumer capitalism, too fell short. Instead he found that the new modes of organization of capital that came to the fore after World War II overwhelmed both classical and consumer capitalism, and therefore their formal modes of expression, realism and modernism. At that moment he took a turn toward postmodernism, which, to him, explained the contemporary cultural experiences. Anderson goes on to explain that in order to theorize this new experience, Jameson attempted to seek a resolution of the dilemma posed by realism and modernism through the idea of textuality, which he borrowed from the work of Roland Barthes. He was also influenced to seek his answer of postmodernism in "late capitalism" as explicated by Ernest Mendel in a book of that title. Besides that, Baudrillard's idea of simulacrum, and his association at Yale with Robert Venturi and others, and more importantly the "provocation of Lyotard's account of postmodernity" (54) by positing the death of communism as a meta-narrative, pushed him toward the insights of his 1982 lecture in the Whitney Museum of Contemporary Arts.

According to Anderson, the lecture formed the nucleus of Jameson's essay "Postmodernism -the Cultural Logic of Late Capitalism" in which he "redrew the whole map of the postmodern at one stroke" (54). Jameson achieved this prodigious act in five brilliant moves. His first act was to anchor postmodernism as the newest transformation of capitalism, which no critics earlier had perceived. Here Jameson explained the expansion of technology in modern electronics, growth of media conglomeration with unprecedented global power, intensification of speculative economy and outsourcing of manufacturing operations to cheap locations overseas. The rise of new modes 
of production and economy meant that modernization was complete, and culture had "necessarily expanded to the point where it has become virtually coextensive with the economy itself" (55) giving rise to the postmodern condition. The second move was the linking of this development of the object world to the postmodern subject. Here Jameson identified the death of the subject since any active sense of history was lost by then. Instead, the sense of perpetual presentness has dominated contemporary sensibility. Due to the "electronic unification of the earth" (56) and the simultaneous presentation of events as images of spectacle that often "exceed the capacities of perception" (56), we today exist in a world of spatial presentness that has overtaken temporal depth.

Jameson's third move was to expand the scope of postmodernism to include "virtually the whole spectrum of the arts, and much of the discourse flanking them" (57-58). Like his predecessor, architecture was foremost in Jameson's discussion of the postmodern. But unlike them he also brought cinema and its history, and the interpenetration of graphic design and advertising under the purview of postmodern discussion. His discussion led him to assert that the new modes of production privileged the image over the verbal. Furthermore, he identified that postmodern art, especially literature, relied on the use of pastiche, a playful imitation of the old without intended satire. Simultaneously, he found that the academic "discourses concerned with cultural field have undergone implosion of their own" (61). The modernist structural differentiation of various academic disciplines in the arts and social sciences had broken down and a more hybrid and overlapping field of inquiry had evolved, one that relied on commentary. Jameson's fourth move consisted of identifying the social bases and geopolitical pattern of postmodernism. He saw the dissolution of the older class system. In the postmodern society, he explicated that there is a newly created class of affluent people caused by the growth of the service and speculative sectors in the developed capitalist societies while above them exist the multinational corporations that wield command over the global economy. Below them exist the segmented and weakened groups, "typically based on sexual and ethnic differences" (62). Such a condition has eradicated the difference between high and low culture. So, a populist postmodern style, created by capitalist commodification, has dominated the cultural landscape of all classes. Hence, the postmodern is said to be hegemonic and global in scope. Finally, Jameson's most original idea, according to Anderson, was to desist from moralizing against the postmodern condition. He enunciated a response whereby "the dialectical task was to work our way so completely through it, that our understanding of the time would emerge transformed on the other 
side" (65). His attempt was to comprehensively theorize the condition so that it can be grasped from within the system.

Precisely at this point Harvey's project deviates from Jameson's, and by extension from Anderson's. Harvey finds the postmodern condition dangerous for it avoids dealing with the realities of political economy and the facts of global power. He is also sharply critical of the New Left for having "abandon[ed] its faith in the proletariat as an instrument of progressive change and in historical materialism as a mode of analysis" (354). He rues the fact that these critics pay more focus on Foucault and Derrida rather than on Marx. Rather than "invoke economic determinism," they insist "that it [is] culture and politics that matter" (354). Considering Harvey's lamentation, it is obvious where the trajectory of his project will lead him. He, therefore, sets out to present the nature of the postmodern condition through a thorough dissection instead of merely delineating the evolution of the concept. In order to understand the contemporary condition as a historical construct, he extensively analyzes its antecedent, modernism that Anderson largely seems to avoid. Harvey, interestingly, sees "Modernism [as] a troubled and fluctuating aesthetic response to conditions of modernity produced by a particular process of modernization" (99). From such a conclusion, he determines that the analysis of the nature of modernization, as posited by Marx, would similarly provide the rationale for the development of the condition that we today term postmodern since for him postmodernism is a more severe crisis within modernity. The logical conclusion for him is, therefore, to analyze the nature of modernization historically.

Harvey begins by showing how modernization consequently led to time-space compression owing to the desire to increase production and earn profit. Early in the rise of the capitalist system, employers realized that time management was very important for increasing capital. Merchants began to better manage time bringing an end to the agrarian notion of life/time. Command over labor time gave profit to capitalist society. Then due to pressure of competition and overproduction, the search for new markets and resources resulted in the discovery and mapping of the world. Furthermore, to save time, inventions like railways, motorized ships, telegraphs, telephones etc were made, which resulted in the compression of both time and space.

Like all Marxists, Harvey believes that capitalism as a system has some inherent defects. To him, the first capitalist crisis that was felt all over the world was the depression in Britain in 1846-47. The crisis occurred because of the fluctuating financial conditions: reckless speculation and over-production. It shook confidence, and challenged the bourgeoisie sense of history (time) and geography (space). That is, the 
progressive sense of time (Enlightenment notion) was questioned. The age also challenged the idea of space since any crisis or revolt now no longer took place in isolation but reverberated throughout Europe. A sense of the stable space was now replaced by a shifting relative space.

The changing sense of time and space resulted in the development of a new sensibility that we later termed as modernism. Harvey sees modernity as characterized by the tension to unify the ephemeral and the fleeting with the eternal and the immutable. Since he locates modern life as suffused with the fleeting, ephemeral, the fragmentary and the contingent, he concludes that it can have no respect for its own past. The transitory of things makes it difficult to preserve any sense of historical continuity. So, modernism entails a ruthless break from all historical condition, a never-ending process of internal raptures and fragmentation within itself. Initially, even the Enlightenment thinking embraced the idea of progress through a break with history. Hence, modernity saw transitoriness and the fleeting as necessary condition through which the modernizing project could be achieved.

But the twentieth century brought the World Wars I and II, and that shattered this optimism. This was reflected in the critical project of Horkheimer and Adorno. Science and rationality had lost ground by then. Some supporters, however, saw in it the idea of "creative destruction." Creation for them could only come through destruction, in fact through total destruction of the formal structures of the past. Moreover, the loss of legitimacy of science and rationality meant the rise of aesthetic experience over everything else, even beyond good and evil. This became the modernist project, and artist now had a creative role to play. These artists were also preoccupied with language because they searched for special modes of representation of eternal truths within the ephemerality and fleetingness. They could "speak of the eternal only by freezing time and its fleeting qualities" (21). Moreover, commodification of artwork forced artists into a market of competition, which reinforced the processes of "creative destruction" within the aesthetic field itself. That meant modernist artists had to assume an aura of creativity (Benjamin's term) for them to look original and unique so that their artwork was immediately marketable. This resulted in a "highly individualistic, aristocratic, disdainful (particularly of popular culture) perspective" (22) among artists who in a sense "constructed and re-constructed our aesthetic tastes" (22). Through the notion of "creative destruction," therefore, artists defined artwork for the public, and that saw the rise of the avant-garde.

Simultaneously, Harvey conducts a thorough analysis of the modernization process during the rise of high modernism to illustrate that 
postmodernism is a greater crisis within modernity. He notes the new development of Fordism in the economic production sphere that started with the introduction of the assembly line production of cars. The result was mass production and consumption. It gave rise to corporate power, and there rose a belief that a new kind of society could be built by proper use of corporate power. But the great depression of 1930 was a big blow. So, state intervention and regulation came into force to overcome this crisis. Only after 1945, the proper configuration and deployment of state powers was resolved and it brought economic boom that stayed till 1973. But Fordism and Keynesianism could not contain the inherent contradictions within the capitalist system, and the consequence was the crisis of 1973. Interestingly, according to Harvey, it was the success of Fordism that resulted in the crisis. After the World War II, Fordism gained popularity and spread to Europe and Japan. America explored international markets and rapidly a global market developed establishing a new kind of capitalism. Service sectors like banking, insurance, hotels, airports, and finally tourism grew. American hegemony did not last long though, as shortly, Japan and Europe became America's competitors leading to the saturation of the American market. Declining productivity and profitability after 1966 meant the beginning of a fiscal problem that accelerated inflation in the US, which destabilized the US dollar leading ultimately to its devaluation. Fordism and Keynesianism could not find a way out of the problem. Any attempt to reduce the rigidity of the system resulted in labor strikes and labor disruptions (1968-72). The only flexibility lay in the monetary policy, in the capacity to print money and keep the economy stable. The consequence was the sharp recession of 1973. This meant the capitalist system had to find means to stabilize the economy quickly.

According to Harvey, the capitalist response to this crisis was flexible accumulation that directly attacked the rigidity of Fordism, and which incidentally initiated the postmodern condition. The crisis of 1973 led to "strong market volatility, heightened competition, and narrowing profit margins" whereby employers took "advantage of weakened union power and the pools of surplus workers to push for more flexible work regimes and labor contracts" (150). Most workers thereafter worked part time with only the core group of permanent management. This enabled the company to fire workers during recession and to hire them in times of increased demand. The schedules were also made more flexible, more working hours when the demand was high and fewer hours when the demand was slack. Moreover, organized subcontracting grew giving rise to "small business and even permitted older systems of domestic, artisnal, familial (patriarchal), and paternalistic labor system" (152). The need to "accelerate turnover time in 
consumption has led to a shift of emphasis from production of goods (knives, forks etc. that have substantial lifetime) to the production of events (spectacles that have instantaneous turnover time)" (157). It has resulted in the "emergence of new sectors of productions, new ways of providing financial services, new markets [...] greatly intensify[ing] rates of commercial, technological, and organizational innovation" (147). In addition, what differentiates flexible accumulation from Fordism is the growth and empowerment of the global financial market. All of these, according to Harvey, entailed a new round of "time-space compression" leading to the creation of the postmodern condition.

Harvey, therefore, sees postmodernism as our aesthetic and cultural response to unprecedented "time-space compression" brought about by the historical churning of the capitalist wheel (recurring crisis and the response to overcome it). Our perception of time and space has always undergone considerable changes. For Harvey, aesthetic and cultural practices are susceptible to our changing experience of space and time. The crisis of 184647 resulted in the Modernist movement. The resultant aesthetic movement was a response to the crisis of our experience of space and time. Artists tried to capture this change in their experience: Joyce, De Chirico, and Proust experimented with time while Picasso and Braque experimented with space. Likewise, the crisis of over-accumulation of materials that began in the late 1960s through 1973 has brought about significant changes in aesthetic and cultural sensibilities. Those alterations include change in our experience of time and space, the collapse in the confidence of "the association between scientific and moral judgments," triumph of "aesthetics over ethics," domination of "image over narratives," precedence of ephemerality and fragmentation over "eternal truth and unified politics," shift in the discussion from "material and political economy" toward "cultural and political practice" (328). These changes mean there is an emphasis on the values and virtues of instantaneity (fast food etc.) and disposability (cups, plates, values, life-style, stable relationships, attachment to things, received ways of doing and being etc.). There is manipulation of tastes and opinions through images. Major concern for the corporations now is more on the production of signs, images and sign system than on commodities. Hence, the proliferation of ephemerality, collage, fragmentation actually mimics the conditions of flexible accumulation. On the other hand, the greater the ephemerality, the more the desire to hold on to some eternal truth, the desire to search for personal or collective identity, the search for secure footings in a shifting world. But the capitalist answer to such a desire is to mimic the past. The home, therefore, becomes a museum and the cities try to provide a distinct 
traditional image and atmosphere through architecture and location intended to attract more people and more profit. Herein lies Harvey's theorization of the pastiche that Jameson so insightfully propounded as a striking feature of the postmodern condition.

Culturally, flexible accumulation has produced a greater attention to quick-changing fashions. Consequently, "The relatively stable aesthetic of Fordist modernism has given way to all the ferment, instability, and fleeting qualities of a postmodernist aesthetic that celebrates difference, ephemerality, spectacle, fashion, and the commodification of culture" (156). Besides, the emphasis on competition has also given rise to entrepreneur culture not just in business sector but also in urban governance, research and development, and even the academic, literary and artistic world. At the same time, as noted earlier, it has also raised a heightened desire for stable values of basic institutions - family, religion and state, at the time of increased fragmentation and economic insecurity.

Though both Anderson and Harvey adopt different approaches in analyzing the postmodern condition, their ideas converge in the notion of the postmodern encompassing the totality of our life experience. Significantly, Anderson sees three coordinates of development as markers for the periodization of postmodernism, which are not very different from Harvey's. He points to the dissolution of the bourgeoisie class; the rise of technology, especially the media; and the surrender of all political alternatives to the Right as the perfect condition that gave rise to postmodernism. All of these, according to Anderson, took place within the twenty years after the World War II creating the condition for postmodernism. Analogous to Harvey, Anderson explains that the post war boom in the economy came to fade because of slower growth rate and increasing international competition around late 70s. Anderson's documentation of the response by the capitalist regime sounds very much like Harvey's flexible accumulation, "battering down of labor in core regions, outsourcing of plants to cheap wage locations in the periphery, displacement of investment into services and communications, expansion of military expenditure, and vertiginous rise in financial speculation at the expense of innovative production" (92). Consequently, according to Anderson, all of these resulted in the Reagan recovery on 12 August 1982, clearly illuminating the conditions of postmodernity which led Jameson to give his speech at the Whitney declaring postmodernism to be the logic of Late Capitalism.

Unlike Anderson, Harvey does not provide a definite date signaling the arrival of postmodernism. He, nevertheless, has the specific year of 1973, when the crisis of over-accumulation led to the transition toward flexible 
accumulation. His theorization of the transition is more Marxist than Jamesonian because he bases his idea on the conditions of productions and capital that, for him, directly determine our daily experience. For Harvey, flexible accumulation is the latest responses to the inherent problems of overaccumulation within capitalism. So, this reaction is not something new, but only a simple recombination of the two basic strategies, which Marx had defined, for procuring profit. It calls for reducing the living standard by eroding the real wage or by "shifting corporate capital from high wage region to low wage region" (186). The second strategy is to make changes in the organization and technology so that "the cost of goods that define the standards of living of labor is reduced" (186). Interestingly, this provided the emergence of highly skilled labor powers because of capitalism's reliance on mobilization of intellectual labor as a means of raising capital.

For Harvey, because "capitalism is expansionary and imperialist, cultural life in more and more areas" (344) is brought within the purview of the materialistic interests. As noted earlier, with newer and flexible means of production, occupations in finance, real estate, law, education, science, and business services grew tremendously. The emergence of these occupations, especially in the financial sectors, created a new class that has provided "a powerful source of demand for new cultural forms based on fashion, nostalgia, pastiche and kitsch, all that we associate with postmodernism" (348). So, the new age has become an era of consumption, of changing fashion of not just clothes but of life-styles and recreational activities. Since there is a drive to make more profits, which is limited by physical goods, therefore, the capitalists have turned to marketing ephemeral services.

Furthermore, according to Harvey, "one of the prime conditions of postmodernity is that no one can or should discuss it as a historicalgeographical condition" (336). We talk of it only in terms of being and not becoming. The focus is on the present and all discussion or evaluation is anything but self-referential. The domination of images over narrative has created the optimum condition for the development of the present sensibility. With modernism we had experienced a rupture with the past; the sense then was that we had to dismantle the past to create anew. But with postmodernism the break has become complete, and so it has intensified our experience of presentness. The past can now only be experienced nostalgically. In sum, for Harvey, the postmodern condition is the result of "voodoo economics" (speculative and fictitious capital), "political image construction and deployment" (e.g. Ronald Reagan), and the growth of "a new social class" (middle class) (336). Herein we find 
Anderson's three coordinates converging with Harvey's favorable climate for the creation of the present condition.

In spite of the striking similarity in their conceptualization of the postmodern condition, Harvey, differing from Anderson and Jameson, finds postmodernism dangerous for he believes that its rhetoric avoids dealing with the realities of political economy and the consequence of global power. $\mathrm{He}$ states that the resurgence of the economy in the 1980s did not create an egalitarian society, but instead it created homelessness, disempowerment and impoverishment. Instead "'Otherness' was produced with a vengeance and vengefulness unparalleled in the post-war era" (332). These people's voice went unheard. Interestingly, most of the current post-war rhetoric justified "homelessness, unemployment, increasing disempowerment etc. by appeal to supposedly traditional values of self-reliance and entrepreneurialism" (336). Such rhetoric means that there is a greater appreciation of aesthetics over ethics. The danger, according to Harvey, is that if " "poverty and homelessness are served up for aesthetic pleasure,' then ethics will indeed be submerged by aesthetics and the world will be led only by charismatic politics and ideological extremes" (337). Hence, Harvey asserts a more engaging response to the postmodern condition.

Unlike Jameson, who desists from moralizing against the postmodern condition, Harvey's answer lies in historical materialism and the Enlightenment project. To Harvey, our understanding of the postmodern condition as a spatio-temporal (geographical-historical) condition is paramount since postmodernism is but the outcome of a new phase of economics and history affecting our culture in ways we had never known or anticipated. Only such an understanding will provide us with the critical edge "to launch a counter attack of narrative against the image, ethics over aesthetics" (359). Harvey sees a way out of the condition; he attempts to provide agency by constructing a narrative of the capitalist history to overcome the banality of a depthless life. Within his theorization of the postmodern condition, he tries to provide voice to those groups who have been ostracized and neglected in the world driven by ephemeral, fleeting, and illusory images.

Interestingly, Harvey tends to see cracks in the economic performance of the capitalist world, and therefore, in the postmodern condition. For him the volatility of the international currency market, the social movements in the US, the labor strikes in Germany and Belgium, fight against world hunger, racism, and ecological destruction, the geopolitical stress between the East and the West are all small but definite indications of the changing nature of the postmodern condition. He argues 
that even deconstruction, the intellectual edifice of postmodernity, has been put on the defensive by the controversies surrounding Heidegger and Paul de Man's Nazi Links.

What is fascinating about Harvey's analysis is that we can test his theory, for the next crisis within the capitalist world is just round the corner. The indication of the crisis is intensifying even as I write. Fareed Zakaria, in his review of Thomas Friedman's insightful book The World is Flat: A Brief History of the Twenty-First Century explains what Friedman terms as the emergence of the flat world. Basically, according to him, Friedman describes the next phase of globalization. He explicates that the economic playing fields are being leveled. The first major cause, as Friedman points out, is the wiring of the world by telecommunication companies during the nineties expecting huge profit. Instead it brought down the costs of phone calls, internet connections, and data transmissions bankrupting many of the same companies. But that meant the good work had been done. Secondly, Friedman assigns it to outsourcing. With the wiring of the world and the stock market crash, the companies had to find cheaper means of production in other countries. The problem of $\mathrm{Y} 2 \mathrm{~K}$ and its solution by outsourcing jobs to India provided the impetus to this shift. The third reason was the "development of 'work flow platforms,' software that made it possible for all kinds of computer applications to connect and work together" (Zakaria 2). These developments mean that besides opening up immense opportunities for the corporations to profit from the newly emerging markets in China and India, Western jobs are being outsourced in large numbers. Furthermore, now with the economic playing field leveled, a reverse brain drain is taking place. Where America used to rely on immigrant scientists to fulfill its demand, now there is a danger of a sharp drop in the recruitment of scientists propelling the fear of reducing American competitive edge in the world. But the immediate danger is the mounting trade deficit, rising resentment of job outsourcing and America's dependence on the Chinese suppliers to fulfill its need for consumer goods. What needs to be seen is whether "the postmodern spirit could take another turn" (Anderson 135). Could the condition be just right for such a turn?

Considering the above given fact about the rise of China and India as the new economic forces in the $21^{\text {st }}$ century, it is but logical to analyze the development of a cultural phenomenon in one of these regions. In the February 14, 2000 issue of BBC News website, there appeared an article titled "India Takes Valentine's Day to Heart." Such headlines are common feature in the subcontinent's media these days. The article reads, "In India, Valentine's Day hype has truly caught on in the last few years, and a whole 
new industry is now established to market 'love"" (Srivastava). One interesting feature about this transformation in the Indian cultural landscape is the role of media. Certainly, this is a cultural import, but deftly manipulated by entrepreneurs to strike rich. Even as the land of Kamasutra and the Khajuraho temple (and though within the Hindu tradition there are days to celebrate every other occasion, even love as exemplified between Lord Krishna and Radha, his consort), India strangely does not have a separate day for the celebration of personal love where one can display one's affection for the beloved. As noted in the 2000 BBC article of Valentine's Day, "That ancient tradition of love [Kamasutra and Khajuroah] died somewhere in the Middle Ages." Since then, display of affection was even frowned upon. A culture developed that believed in simplicity and frugality; but all was to change with the onslaught of the capitalistic culture.

But first let us examine how Valentine's Day is celebrated in India. It is driven by excessive commercialization and marketing gimmicks. Srivastava writes, "Everything from mobile phones to mood candles, dance academies, websites, ballpoint pens, and even bottled mineral water is being sold in the name of love" (BBC, 2000). Bantwal Shobhan, an Indian from America writing about Valentine's Day celebration among Indian community, mentions that the concept as such is not a problem but the rampant commercialization is. He shares his experience of seeing "a giant, larger-than-life heart covered in red neon lights displayed on a major thoroughfare in Mumbai [...] and [expresses] how a sentimental festival had turned into an advertising eyesore" (2). There are also other examples of marketing blitz associated with Valentine's Day: in Mumbai a restaurant "offered 50 free lunch for the best Valentine's Day message," and an ice cream maker "tried to get free publicity into the record books by putting up the biggest Valentine's Day card" (Srivastava). In addition, another article reads, "Commercial TV channels invented special Valentine shows, dedications of love filled radio programs and even love letter competition were held" (BBC, 2002). At the same time, however, there are threats, attacks and disruptions during the occasion from the Hindu hardliners. On February 14, 2001, "Activists from the hardline Shiv Sena party attacked the busy fast-food Wimpy restaurant in Delhi, throwing chairs and smashing plants" (BBC). Authorities have had to beef up security to restrict violence. The occasion brings social tension, and yet "young lovers throng [...] malls and restaurants in major cities" (BBC, 2001). In spite of the threats and violence, young lovers buy roses, chocolates, and heart-shaped balloons for their loved ones. 
There is no doubt that American influence is big in the popularity of Valentine's Day and several cultural crossovers into Indian society; however, there are some interesting parallels to economic conditions, rise of the middle-class, and the spread of cable television that has perpetuated the growing commercialization and popularity of what should have remained a sentimental celebration of love. Interestingly, "Most desis [Indians] who grew up in pre-1990s India had never heard of Valentine's Day" (Bantwal 1). So, to figure out this rise we have to, taking cue from Harvey, look at the historical changes in the economic scenario of the country during the period to figure out how the Valentine's Day culture was imported into the country and what accounts for its immense popularity.

Stanley Fisher, the First Deputy Manager of IMF in his January 22 speech in the "India Today" conclave explains the reasons for India's recent economic growth, which he says, began with the severe foreign exchange crisis in 1991:

The driving force behind [the] social and economic improvements [in India] was the ambitious reform program undertaken in the wake of the balance of payments crisis in 1991. The crisis was a painful but valuable wake-up call. The reform program that followed marked a new willingness to allow market forces the freedom to work. It included: significant industrial and trade liberalization; financial deregulation; improvements to supervisory and regulatory systems; and policies more conducive to privatization and foreign direct investment. These changes reawakened what Keynes called the "animal spirits" of India's entrepreneurs, and gave a sharp boost to growth.

India's response to its 1991 crisis compares to earlier capitalist system's response as enunciated by Harvey. Shortly, the economic reform not just increased the purchasing power of the existing middle class but also increased its number. Besides, the reform intensified liberalization in every field, including television. The television boom brought dramatic changes in Indian sensibility, especially in urban spaces. Herein Anderson's remark about television is validated: "If there is any single technological watershed of the postmodern, it lies here" (88). Consequently, Indian society was to face a rude shock with the growth of TV.

Reading through the history of television in India, we can note that its growth corresponded with Indian economic liberalization in the nineties:

[The growth of TV in India came in] early nineties with the broadcast of satellite TV by foreign programmers like CNN followed by Star TV and a little later by domestic channels such as Zee TV and Sun 
TV into Indian homes [Government regulation was relaxed during the 90s]. Prior to this [...] Entertainment programmes were few and far between. [...]. When, urban Indians learnt that it was possible to watch the Gulf War on television, they rushed out and bought dishes for their homes. Others turned entrepreneurs and started offering the signal to their neighbours by flinging cable over treetops and verandahs. From the large metros satellite TV delivered via cable moved into smaller towns, spurring the purchase of TV sets and even the upgradation from black and white to colour TVs. DD [the national TV channel] responded to this satellite TV invasion by launching an entertainment and commercially driven channel and introduced entertainment programming on its terrestrial network. This again fuelled the purchase of sets in the hinterlands where cable TV was not available.

The initial success of the channels had a snowball effect: more foreign programmers and Indian entrepreneurs flagged off their own versions. From two channels prior to 1991, Indian viewers were exposed to more than 50 channels by 1996. Software producers emerged to cater to the programming boom almost overnight. Some talent came from the film industry, some from advertising and some from journalism. (indiatelevision.com)

No doubt entrepreneurs grew during this period. And they set out to exploit the new medium to its maximum benefit. The images and messages perpetually bombarded onto the audience had to transfer into realistic capital gains. Corporations and entrepreneurs saw the inevitable result and took to exploiting the growing purchasing power of the emergent class. They attempted to tap into the cultural landscape to reap profit. Television, therefore, became the biggest mode of persuasion, particularly in the urban areas where private television channels beam their programs. Anderson points out that TV "is not simply a wave of images, but also -and above all -of messages [... These are] perpetual emotion machines, transmitting discourses that are wall-to-wall ideology" (89). Corporations and entrepreneurs would not only beam programs consistent with the cultural demand, but they also began to churn programs that rapidly anticipated and also dictated the taste of the people. Emulating Western culture and television programs by manipulating it to local tastes became a big attraction. No doubt, it was during the nineties that Valentine's Day as a concept grew.

Following Harvey's theorization, we can also assign similar characteristics to postmodern conditions in India. As discussed above, the popularity of Valentine's Day also brought strong reactions against it. The forces acting behind the protests and violence were the Hindu 
hardliners who one may say reacted fearing cultural contamination. But at the same time one must note that until 1980s, these hardliners were only active in isolated regions. They were not popular in the whole of the country. But since late 1980s the movement led by the religious groups and parties like Vishwa Hindu Parishad, RSS (Rashtriya Swayamsevak Sangh) and BJP (Bharatiya Janata Party) grew and began taking a national color, culminating in the BJP wresting power in 1996 under a coalition government. I tend to see this sudden sprout of religious and national sentiment more as urban India's rising need to hold on to the past and their search for personal or collective identity faced with the experience of ephemerality and fragmentation of the postmodern world. Significantly, the support for the religious parties and their ideology of Hindutva or Indianness (as the BJP would want to describe it) has mostly remained isolated in the urban centers. Though religious sentiments run strong in many rural places, the tremendous growth of interest in religion among the youths in the urban centers is an interesting phenomenon worth further investigation. Since most of the Indian population still live in the villages, it is not surprising that in the general election of 2004, the NDA (National Democratic Alliance) led by BJP lost to the Congress Party because the benefits of economic liberalization was not reaching the villages. In spite of the tremendous economic growth and the BJP's campaign of "India Shining," the NDA coalition lost the election. The defeat of the BJP and its allies indicate that during the 2004 election religion was not a priority for rural India.

Consequently, since Valentine's Day celebration in India is an urban phenomenon, it elicits a dichotomous sentiment. The same group from the Indian yuppie culture has participated and popularized the adopted tradition in recent times; simultaneously, they have also figured as the force behind the religious revival. The question it begs is, will the Hindu culture through its assimilative strength be able to bring Valentine's Day into its fold so that it does not elicit the antagonistic feelings that it incites today? Whatever the outcome, the role of the media has transformed the Indian society in ways never anticipated before. Similar might be the situation of Nepalese culture and society which requires a different study. The postmodern condition, as discussed by Harvey and Anderson, is not isolated to the American or the European landscape alone. It is a global phenomenon. At the same time, what needs to be seen is how these ancient cultures 
(India, China, and Nepal) will react to the new conditions. For now, however, the reactions seem predictable.

\section{WORKS CITED}

Anderson, Perry (1998). The origins of postmodernity. New York: Verso.

Bantwal, Shobhan (2015). "Money Can't Buy Me Love." India Abroad 5:
21
(2005):
12.
ProQuest.
16 May

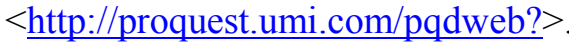

BBC News (2015). "Tough love for Indian valentines." Online Posting. 14

Feb. 2001. 16 May <http://news.bbc.co.uk/1/hi/ world/south asia/1169077.stm>.

--- (2015). "India's fascination with valentine's Day." Online Posting. 14 Feb. 2002. 16 May <http://news.bbc.co.uk/2/hi/ south asia/1820440.stm>.

Fisher, Stanley (2015). "Breaking Out of the third world: India's economic imperative." Addressed at India today conclave in New Delhi on 22 January 2002. International Monetary Fund. 22 May $<$ http://www.imf.org/external /np/speeches/2002/012202.htm>.

Harvey, David (1989). The condition of postmodernity. Cambridge: Blackwell.

Indiatelevision.com (2015). "India's television history: A snapshot of Indian television history." Online Posting. 2001. 22 May

$<$ http://www.indiantelevision.com/ indianbrodcast/history/ historyoftele.html>.

Srivastava, Sanjeev (2015). "India takes valentine's day to heart." $B B C$ News. Online Posting. 14 Feb. 2000. 16 May $<$ http://news.bbc.co.uk/2/hi/south_asia/642644.stm $>$.

Zakaria, Fareed (2015). "“The World is flat': The wealth of yet more nations." Rev. of the World is flat: A brief history of the twentyfirst century, by Thomas L. Friedman. New York Times. Online Posting. 1 May 2005. 25 May 2015. $<$ http://www.nytimes.com/2005/05/01/2 books/review/ 01ZAKARIA.html>. 